\title{
Diasporic Dilemma in Amit Chaudhuri's Afternoon Raag
}

\author{
Asfar Sadath K \\ Assistant Professor \\ Department of English \\ Sullamussalam Science College \\ Areekode, Kerala, India \\ ashfar.clt@gmail.com
}

\begin{abstract}
Identity is one of the important themes of the diasporic writing. Identity plays an important role in an immigrant's life because they feel rootless and nostalgic when they try to become members of a new group. There are different aspects of identities like political, social, cultural, economic and individual and so on. These are playing an important role in an immigrant's life. The concept of home always gives a sweet feel for immigrants. A sense of belongingness plays an important role in immigrant life. Immigrants never accept the host country as their country.
\end{abstract}

Keywords: Diaspora, Amit Chaudhuri, Indian Writing In English, Postcolonialism, Immigrants

The origin of the Indian Diaspora has always been the regional social structures of the emigrants and migrants. On the basis of regional cultures and languages in Europe, Indian create their Bengali, Punjabi and Telugu Diasporas. However, when there is a question of the Indian Diaspora, they always feel a part of it. It is the shared cultural heritage of Indians which lays the foundation for the Indian Diaspora. At present there are several established 
Diaspora throughout the world. For example Indian Diaspora, African Diaspora, Chinese Diaspora, etc Indian Diaspora is one of the largest Diasporas in the world. People who belong to specific diaspora have different ways of connecting themselves with their homeland. Using a shampoo produced at home in one way of doing it; writing with themes that link him with the homeland another way. It is evident that many people who come under diaspora have contributed to world literature, which has come to be called 'diasporic writing'.

Identity is one of the important themes of the diasporic writing. . Identity plays an important role in an immigrant's life because they feel rootless and nostalgic when they try to become members of a new group. There are different aspects of identities like political, social, cultural, economic, and individual and so on. These are playing an important role in an immigrant's life. The concept of home always gives a sweet feel for immigrants. A sense of belongingness plays an important role in immigrant life. Immigrants never accept the host country as their country.

Amit Chaudhuri, as a part of displaced community explores the problems of immigrants through his novel Afternoon Raag (2012) with his own experiences. Immigrants live with two cultures host culture and home culture. When the question of identity arises, immigrants always go with their own culture. Afternoon Raag opens with a description of place which is the origin of writers. In this novel the narrator uses a lot of descriptions and poses that his culture is superior to the western culture. His comparisons about family life, food, dress and relationship always show that that he is very much proud of his culture and he always wants to be a representative of that. He says, "I would feel an at-homeness and pleasures in their rhythm" (Chaudhuri, Afternoon 11). 
In Afternoon Raag, Chaudhuri depicts the theme of the novel search for identity by focusing on individual's domestic life in a society. This novel is about an Indian male student in Oxford, his loneliness and friendships with Sharma, a north Indian with an accent, and Mandira and Shehnaz, fellow students at Oxford. He is unable to choose between the two girls and his memories of growing up in India. The narrative shifts between Oxford, Bombay and Calcutta, whenever and wherever the narrator's cool gaze turns. The narrator feels that during their parents stay in Oxford they were not comfortable with their lifestyle in Oxford but in Bombay they feel safe and secure even though their son is not with them.

In this novel, Chaudhuri discusses in detail about the protagonist's crisis as a classical singer and as a lover. When he decided to become a great classical singer, he started to practice with his mother, to establish his own identity as a classical singer, he plans to get his own tanpura, and with his guru he went to a shop in Rashbehari Avenue and bought his first tanpura which is ready to play. After getting his own tanpura he enjoys the lesson by playing it under his guru's guidance. His guru taught not only ragas with tanpura but also to tune it and to hold it vertically on the lap while playing and to place it horizontally on the ground.

Before completing his musical lessons, the narrator is yet to go to Oxford for his higher studies. He carries his tanpura with him, when he feels loneliness or homesick in Oxford he starts playing the tanpura and practices ragas. Whenever he plays it or hears classical music he remembers his homeland and his guru singing with his brother Mohan and his brother-in-law

Sohanlal. The narrator says: 
When I hear the raag Maand, I think of my guru and his brother and Sohanlal, for it bears the characteristics, the stamp, and the life of their region. Their faces, their language, the colour of their skin, the cotton clothes they wear, are set and have their meaning against the same landscape. Each raag was once a folk - melody. (Chaudhuri, Afternoon 141)

Often the narrator becomes nostalgic of his motherland, which is evident through the above passage. When he listens to Maand raag, he remembers the picture of his guru singing with his brother Mohan and Sohanlal and he thinks of their colour of skin, language they speak, clothes they wore, etc. They come like flashes in front of his eyes. When the narrator is in Oxford, he gets the news that his guru is dead and he is no more; he feels lonely and he feels that hereafter he will not get any opportunity to sing in a public gathering. The narrator feels that after his guru's death his ambition to become a singer will not be fulfilled. Thus the narrator's identity is a Classical singer remains unfulfilled.

Chaudhuri explores the narrator's identity as a successful lover. During his stay at Oxford for his higher studies, he develops an intimate relationship between two girls-Mandira und Shehnaz as the name indicates the first is a Hindu and the second a Muslim girl. In the beginning of the novel the narrator is in a dilemma in choosing one of the two girls. Through this Chaudhuri also agrees that the age around thirty, is the age which has all options and opinions which do not make them choose their wants and needs. Everything is in becomes dilemma

Shehnaz is an Indian girl who goes to Oxford for her higher studies. Like the narrator, she also feels lonely and homesick and wants to get rid from this alienation. She is also in 
search of right company in Oxford. Shehnaz got married once and got divorced, to overcome her loneliness or depression. She is in search of a good company who can console her. She needs a shoulder to lean upon. Through a friend, the narrator meets Shehnaz and they both develop friendship thinking that Indian student will be comfortable and right company to them. Later their friendship develops into a relationship as a lover. They both love and she offers herself to him. Though they loved each other, the narrator had confusion that he is not emotionally attached with Shehnaz, because at that time he falls in love with Mandira, a Hindu girl. This shows that his identity as a lover is in question.

Mandira is also an Indian student in Oxford, like Shehnaz, to drive her alienation out: she got the narrator's introduction as a friend later this relationship also developed as a lover. He makes many promises to her but fails to fulfill them; he fails to satisfy her demands. While Mandira realized that the narrator is not the right person for her love. She got depressed and postponed her final exams and leaves the college. Through this, his relationship with Mandira comes to an end. He keeps on changing his mind between these two girls. He is in dilemma about his love for Mandira and Shehnaz, which he is not able to choose. Shehnaz is in love with the narrator while the narrator is in love with Mandira. Caught in the love triangle his alienation is driven from Oxford but he is not sure in his relationships with both the girls.

Unlike Mandira, Shehnaz recovers from depression and faces her final exams successfully and moves to America after her exams. After the exams for summer vacations the narrator returns to Calcutta and writes a letter to Shehnaz asking sorry and to renew their love, but he decides not to send the letter to her. This shows that still the narrator is not confident in his decision and still he is in confused state of mind. Through this his love towards 
Shehnaz comes to an end. Again his identity as a successful lover to Shehnaz also comes to an end.

According to Chaudhuri love has no permanent place in a student's life at college. In this novel also there is no any particular reason for the narrator's love failure. Thus, the narrator fails in achieving his ambition and his search for identity as a Classical singer as well as a successful lover. His identity as a singer is not fulfilled due to his guru's death and secondly, his identity as a lover is not fulfilled because of his unsteady mind in decision making.

Amit Chaudhri clearly represents the attitude of the current generation, which does not take love and life seriously. Westerization is dominant in the immigrants though they have nostalgia. They do not follow Indian culture and yet yearn to be an Indian. They fall a prey to the western fantasy. Hence Amit Chaudhuri's Afternoon Raag plays the tune of identity crisis which is evident among immigrants. Thus Chaudhuri represents the stark reality prevailing in the society. 


\section{Works Cited}

Chaudhuri, Amit. Afternoon Raag. Penguin Books, 2012. Print.

Kadekar, Laxmi Narayan. The Indian Diaspora. Rawat Publication, 2009. Print.

Rajesh, and K. Shashikantha. "Identity in Indian Diasporic Writing." Eclectic Representations 3.1 (2013). Print. 